\title{
POLICY IMPLEMENTATION FOR HIV/AIDS AND SEXUALLY TRANSMITTED INFECTIOUS DISEASE PROGRAMS IN THE FIRST LEVEL OF HEALTH FACILITY
}

\author{
Suparmi $^{\mathrm{a}}$; Triana Sri Hardjanti ${ }^{\mathrm{b}}$; Hesti Kurniasih ${ }^{\mathrm{c}^{*}}$ \\ a,b,c Poltekkes Kemenkes Semarang ; Tirto agung street; Semarang 50268 ; Indonesia
}

\begin{abstract}
The number of HIV/AIDS and Sexually Transmited Infectious Diseases (PIMS) incidence in Indonesia, especially in Central Java are growing every year. Provincial government set a regulation in controlling disease that refers to the HIV/AIDS Control Program and PIMS in the First Level of Health Facilities by the Ministry of Health in 2016. It is hoped that this program can break the chain of HIV/AIDS and PIMS cases while at the same time making a generation that healthy and productive quality. The aim of this study was to determine the implementation of programs to control HIV/AIDS and PIMS in Banyumas regency. The design of this study was descriptive qualitative through in-depth interviews. The main informants were ten HIV Counseling and Testing (KTHIV) of Public Health Center, triangulation informants were People Living With HIV/AIDS (PLWHA) patients, Clinical Doctors, Head of Department of Health Services P2P. The data were collected by in-depth interview technique. In addition to the interview, a survey was also conducted with PLWHA. Processing and analysis of data were using taxonomic analysis. The implementation of HIV/AIDS control program policies has not been optimal in its implementation. The lack of optimal implementation of HIV/AIDS and PIMS prevention policies is due to several aspects, i.e. policy accuracy, implementation accuracy, target accuracy, environmental accuracy, and process accuracy. Increasing monitoring and evaluation related to a program's policies is needed. Morover, it is important to improve the quality of human resources and careful planning related to the control program.
\end{abstract}

Keywords: HIV/AIDS; sexually transmitted infections diseases; health care reform

\section{Introduction}

Health development efforts in Indonesia have been carried out by the government in collaboration with the World Health Organization or WHO (World Health Organization) and various other developing countries to create a program called the Millennium Development Goal's (MDG's) which is targeted to be carried out for fifteen years since in 2000 to 2015, where in this program there were 8 (eight) goals to be achieved, one of which was HIV/AIDS prevention. However, during the fifteen years MDG's could not achieve all the targeted goals, so this program had to continue with a different name known today, SDG's or Sustainable Development Goals. In the next

*) Corresponding Author (Hesti Kurniasih)

E-mail: hesti.kurniasih@poltekkes-smg.ac.id fifteen years from 2016 to 2030 SDG's must complete what MDG's could not achieve in the previous fifteen years. One of them is the sixth goal of HIV/AIDS. (Kemenkes, 2017)(Agustino, 2008).

To overcome the problem of the high number of cases of HIV/AIDS that occurred, the provincial government set a regulation in controlling HIV/AIDS, which refers to the HIV/AIDS and Sexually transmitted infectious disease (PIMS) Control Program at the First Level Health Facilities by the Ministry of Health in 2016. The HIV/AIDS and PIMS Control Program in the First Level Health Facility by the Ministry of Health in 2016 contains an implementation package for the HIV/AIDS Control program in First Level Health Facilities (FKTP) that covers the identification and analysis of the magnitude of the problem, prevention 
efforts, new case finding, diagnosis, enforcement of opportunistic ingections and discovery of opportunistic ingections and determination of clinical stage, cotrimoxazole prophylaxis, TB-HIV Co-infection treatment, good chronic care, administration of ARV drugs, prevention of HIV transmission from mother to child (PPIA), control and treatment of STIs, reduction of adverse effects of drug abuse and injections (PDBN) to monitoring and evaluation. (Agustino, 2008).

However, this regulation is still considered ineffective in its implementation, because there are problems in its implementation. A factor which was felt to be lacking in this policy was in the socialization of this regulation. Many people and related parties do not know about this policy. The issue of funding will also be felt that needs attention, because it cannot be denied with many programs that are run that require no small cost. Another thing that influences is the environmental conditions surrounding the application of this policy. The bad stigma that already exists in the community, makes the community indifferent and rejects if there are people with HIV and AIDS in the surrounding environment. The discrepancy arises what is desired and what is done in the implementation of this policy. This makes the objectives of the policy cannot be fully achieved. Therefore, based on the description above, the title raised is the Implementation of HIV/AIDS and PIMS Control Program Policies at the First Level Health Facilities in Banyumas Regency.(Ministry of Home Affairs., 2004; Kemenkes, 2017)(Agustino, 2008).

\section{Method}

Type of research is descriptive which aims to make a picture of a situation objectively in order to solve or answer the problems that are being faced in the current situation, especially in the field of health services in order to make improvements and improvements to health care programs. This study describes the Policy Implementation of the HIV/AIDS Control Program (Human Immuno-Deficiency Virus/ Aquired Immuno Deficiency Syndrome) and PIMS (Sexually Transmitted Infectious Diseases) in First Level Health Facilities in Banyumas District (Moleong, 2003).

Population or research subjects in this study are stakeholders secondary and stakeholders, primary as well as the factors supporting and inhibiting factors in HIV and AIDS prevention policy in Banyumas. To check the validity of the data, the researchers took information from the Head of the P2P Office of the Banyumas District Health Office, Clinical Doctors and HIV Counseling and Testing (KTHIV) officers at first level health facilities as well as Clients or people with HIV/AIDS and sexually transmitted infectious diseases (M. Irfan., 2007).

Validity Test in this study uses triangulation of sources, to compare the findings of key informants with triangulation informants. In this study the data obtained were analyzed based on their contents or substance called content analysis. In the content analysis the things analyzed can use taxonomic analysis. In content analysis the focus of the research seeks to describe or explain the phenomenon or focus that is the target of all.

\section{Result and Discussion}

After in-depth interviews with key informants namely HIV Counseling and Testing (KTHIV) officers, Clinical Doctors and the Head of the Banyumas P2P Health Office, the results of the implementation of the preparation, implementation and reporting stages are as follows:

\section{Preparation Phase}

Based on interviews with informants and triangulation informants, it can be concluded that the identification process has been carried out. Identification aims to find out how many people have HIV/AIDS and PIMS. In this program all sufferers are identified. This is in accordance with the basic approach of the HIV/AIDS and PIMS Control program in first level health facilities including identification and analysis of the magnitude of the problem, prevention efforts, new case finding, diagnosis, opportunistic infection finding and clinical stage determination, cotrimoxazole prophylaxis, TB-HIV Co-Infection treatment, good chronic care, administration of ARV drugs, prevention of HIV transmission from mother to child (PMTCT), control and treatment of STIs, reduction of the adverse effects of drug abuse and injection (PDBN) to monitoring and evaluation. (Director General of Public Health, 2016).

The following is an excerpt from an interview with HIV Counseling and testing informant "We are in HIV control, we first find the case from the examination at clinic and then if there are symptoms that lead to HIV sent to me for counseling and VCT. Pregnant women must 
be examined. Usually we also have a request for cooperation between VCT and NGOs at the end of the year. We also go to the alley conscious of only blood samples. Whereas those who come directly to the Public health center are usually risk factors". (Widodo Joko, 2002).

Tabel 1. The result the results of interviews conducted with respondents and triangulation

\begin{tabular}{|c|c|}
\hline FKTP Activities & Reality \\
\hline $\begin{array}{l}\text { Identification and analysis of the size of problem in the } \\
\text { working area of public health center }\end{array}$ & $\begin{array}{l}\text { Of all first level health facilities interviewed, most of them stated } \\
\text { that it was only limited to screening, while } 1 \text { all first level health } \\
\text { facilities stated that it was not only screening but also } \\
\text { identification of risk groups. }\end{array}$ \\
\hline Prevention efforts in the community & $\begin{array}{l}\text { All respondents stated that prevention was limited to counseling } \\
\text { and outreach. HIV/AIDS screening tests are only for pregnant } \\
\text { women according to government programs, there are } 2 \text { villages } \\
\text { that have established citizens cares for AIDS but are not yet } \\
\text { running or active. There is one all first level health facilities that } \\
\text { Carries out HIV/AIDS tests for future brides. }\end{array}$ \\
\hline Infection prevention and control in health facilities & $\begin{array}{l}\text { So far, the use of personal protective equipment and infection } \\
\text { prevention according to standards is still limited. }\end{array}$ \\
\hline Post-Exposure Management & $\begin{array}{l}\text { Of all the respondents stated that so far there have been no such } \\
\text { cases if there is food there will be separate sterilization }\end{array}$ \\
\hline New Case Findings & $\begin{array}{l}\text { If there are new case findings, } 10 \text { all first level health facilities } \\
\text { make referrals to Margono Hospital or Banyumas Hospital, while } \\
1 \text { all first level health facilities has services for administering } \\
\text { drugs. }\end{array}$ \\
\hline Diagnosis & $\begin{array}{l}\text { Enforcement of diagnoses through } 1 \text { reagent test, if reactive then } \\
\text { referral to VCT services for reagents tests } 2 \text { and } 3 \text {. }\end{array}$ \\
\hline $\begin{array}{l}\text { Finding of opportunistic infection and determination of } \\
\text { clinical stage }\end{array}$ & $\begin{array}{l}\text { All respondents stated that they had not found opportunistic } \\
\text { infections, if any referral would be made opportunistic. }\end{array}$ \\
\hline Cotrimoxazole prophylaxis & $\begin{array}{l}\text { Of all respondents, I stated that he had given cotrimoxazole } \\
\text { therapy for a further dose from the previous place. }\end{array}$ \\
\hline Management of TB-HIV co-infection & $\begin{array}{l}10 \text { out of } 11 \text { health facilities have carried out VCT examinations } \\
\text { on TB patients, while } 1 \text { puskesmas has not performed this } \\
\text { examination. }\end{array}$ \\
\hline Chronic care was good & All patient were referres. \\
\hline ARV drug & $\begin{array}{l}\text { Administrators giving ARV'sis carried out at VCT services at } \\
\text { Margono and Banyumas Hospital. }\end{array}$ \\
\hline Prevention of mother-to-child HIV transmission (PPIA) & $\begin{array}{l}\text { In accordance with the government program, screening of } \\
\text { pregnant women for mandatory HIV/AIDS testing. }\end{array}$ \\
\hline Control and treatment for STI & It has been limited to referring. \\
\hline $\begin{array}{l}\text { Reducing the adverse impact of injecting drug abuse } \\
\text { (PDBN) }\end{array}$ & $\begin{array}{l}\text { Counseling to youth organizations, schools, WPA, Babinsa for } \\
\text { risk areas, the community of IDU's is examined every } 3 \text { months. }\end{array}$ \\
\hline Methadone maintenance therapy program (PTRM) & None \\
\hline Sterile injectable equipment service program (NSP) & The disposal of syringe waste is carried out by a third party. \\
\hline Recording and reporting & $\begin{array}{l}\text { Monitoring patient data through the application of Siha, for } \\
\text { evaluation reporting } 1 \text { month or } 3 \text { months. }\end{array}$ \\
\hline Analysis of data & $\begin{array}{l}\text { Form } 11 \text { respondents were unable to analyze the number of } \\
\text { PLWHA patients due to limited data acces to find out the number } \\
\text { of existing cases, this was due to the law which stated protecting } \\
\text { or confidentialy in people living with HIV/ AIDS patients. So that } \\
\text { the officers are limited to taking precautions. }\end{array}$ \\
\hline
\end{tabular}

It can be concluded that identification of HIV/AIDS and PIMS sufferers has been carried out in accordance with the respective work areas of FKTP.

\section{Implementation Stage}

At the implementation stage, based on the results of the interviews, most of the prevention has been carried out by officers. Following is the informant's quote "we have made preventive measures in the examination of first trimester pregnant women, tuberculosis patient,sexually transmitted infection diseases patient at the clinic. Identification of the prospective bride and groom has also been done". Another informant said, "Prevention is done through socialization by each village midwife, health promotion also participate if there is mass counseling. If there is a risk we offer it for VCT too. In addition there is also the formation of WPA (Citizens Concerned with AIDS) at the village level in collaboration with AIDS Commission (KPA). 
Based on the results of interviews with triangulation informants, the results obtained "so far yes counseling, socialization, then we test especially pregnant women, TB patients and key populations".

According to the manual, prevention activities are carried out by all first level health facilities through a number of activities involving cross-sectoral and the community in general.

The next stage is the stages of prevention efforts undertaken by the community, following a quote from the informant "Prevention in our community by counseling up to elementary, junior high, high school, classes of pregnant women and empowerment of family welfare. If you go to the fathers rather difficult yes we are. We also don't have a mobile VCT".

The information on prevention efforts at the first informant was justified by the Head of P2P. Following the results of the interview with the Head of P2P "limited to socialization and counseling".

From the above statement it can be concluded that it needs clear rules or agreement on the efforts made by the community in order to succeed government programs related to controlling HIV/AIDS and sexually transmitted infectious diseases.

The basic principle of community empowerment in the prevention and control need to be understood, namely: community organizing (community organization) and community development (community development). Both are oriented towards the process of group or community empowerment towards achieving independence through the involvement and active participation of all group or community members (Suharto, 2008) (M. Irfan., 2007).

The importance of empowerment described by Mutmainah (2014) that related to human resources in the implementation of programs related to the public, it is important to do the implementing empowerment (empowerment).So that resources will be created that have the ability and skills in their fields. So that it will achieve the ability to be effectively efficient in interaction skills, conceptual abilities and administrative abilities (Suharto, 2008) (Thoha, 2008).

\section{Reporting Phase}

Before recording and reporting, there is a monitoring and evaluation process that should be carried out by HIV counseling and testing officers. The flow of reporting and target coverage of cases in the handbook already exist, but based on the results of interviews, the informant was never asked for monitoring and evaluation. As the results of the interview with the main informant follows "there is no data so it cannot be monitored and evaluated. Because the Human Rights Law is a closed patient, if there is a visit from Banyumas, the patient's special right is not made public. Health worker are given access so we can protect ourselves. When there was a workshop meeting in Santika many questioned that too but still could not. Public health center should not know unless Public health center find or have a referral". However, there are other things that are delivered by different officials. "Monitoring and Evaluation we take data at the Public health center from the lab, monitoring also from the village midwife. We are also all TB patients tested for HIV, for clinical doctors as the responsibility".

As for the recording and reporting of each KTHIV officer reporting through the HIV/AIDS information system (SIHA) application, such as the following interview, "Reporting through HIV/AIDS information system is the same as the officers who have been trained. We also have an offline record, there is a form and we report the data to the department," another informant also said it "Yes, that was with SIHA online. The recording of reports which for myself I also have, is manual. "

From the description above it can be concluded that there has been vertical communication in the implementation of this program, but it is still lacking in particular in terms of monitoring and evaluation as well as recording and reporting. Monitoring and evaluation needs to be done periodically and continuously throughout the implementation of HIV/AIDS and PIMS case control activities so that reporting and documentation can be in accordance with reality.

The Health Department and Public health center must be able to work together to supervise based on existing reports. According to Aida Andriani (2018) in her research, the lack of achievements in HIV/AIDS prevention and control programs and PIMS is due to the lack of monitoring and evaluation of policy makers (Ministry of Home Affairs., 2004).

In addition, the availability of facilities and infrastructure to support the prevention and control of HIV/AIDS and PIMS is given more attention given the input from the land, namely 
the lack of supporting infrastructure. Submission of information carried out is marked by the socialization of ongoing programs. The existing resources in implementing this policy also need to be considered according to the number of cases. The influence of the socio-economic environment of a society, especially on the people who are the recipients of the policy, will influence this environment. In addition, the understanding of a policy that will be carried out by the implementing apparatus or implementor will certainly vary from one another. The limitation in this study is that people with HIV/AIDS who are willing to be respondents, at the public health center we use a health center that already has VCT services. (Widodo Joko, 2002) (Suharto, 2008).

\section{Conclusion and Suggestion}

Based on the results of research, the implementation of the HIV/AIDS and PIMS (Sexually Transmitted Sexually Transmitted Disease) Program at Level I Health Facilities was good enough, it was proven that there was a preparatory stage before the control program was carried out, identification of targets, coordination of implementation sites, and socialization of related elements, namely PLWHA sufferers and key groups. At the implementation stage, the control implementation has reached the target. It's just that in this process there are still many things that need to be improved, starting from supporting facilities and infrastructure, guidelines for service guidelines at First level health facilities, implementing officers and implementation sites. At the Reporting stage there has been vertical communication in program implementation in the form of monitoring and evaluation as well as recording and reporting, although not yet optimal. Other factors related to this policy are: Policy accuracy, the implementation of these efforts has not been running optimally and is not in accordance with the development of disease cases. So that it has not reached the desired goal. Accuracy of implementation and implementation of HIV/ AIDS prevention policies have been carried out by appropriate implementing counselors, such as the Provincial AIDS Prevention Commission (KPAP), the Health Office, or related stakeholders who are members of KPAP, NGOs and others. Each counselor has their respective main duties, but there are still some who are not actively involved. Accuracy of targets, the recipients of this policy are the entire Banyumas community, especially those of the target group, those who are at risk of contracting HIV and AIDS and who have been infected with HIV and AIDS or who are better known as HIV and AIDS sufferers. Not all recipients of this policy know about HIV and AIDS prevention efforts. Environmental Accuracy, linkages between good implementing agencies between institutions and others. One thing that still needs attention is to synergize the programs carried out by each agency so that the programs implemented are in accordance with the needs of program recipients people living with HIV/ AIDS (PLWHA).

Process accuracy, the readiness of the implementing counselor still needs to be improved in its implementation. Likewise, the readiness of the community is still lacking because there are still many who do not know about this regulation. Based on the above conclusions, the recommendations that need to be followed up by related agencies in increasing the implementation of HIV/AIDS and sexually transmitted infection diseases prevention programs are. For Related Parties (KPAP/NGO) Review of the Human Rights Law which has more opportunities to protect PLWHA, not those who are still healthy. HIV counseling and testing Implementing first level health facilities. Strengthening coordination between implementing counselors and coordination programs is carried out by holding regular meetings at least once every 3 months between implementers. For Health Services Optimizing the use of print, audio and visual media in disseminating HIV and AIDS prevention programs and information (Hana, Sri Suwitri, 2009) (Commission, 2007). Monitor and evaluate the implementation of HIV and AIDS prevention programs and efforts on a regular basis. Improve the quality of human resources by providing training to implementing counselors. Careful planning of HIV and AIDS prevention programs so that it can measure how much money is needed. This research is related to policies that do not only involve one agency, so the results of this study cannot be directly used as a basis for evaluating policies related to the handling of HIV/ AIDS (Hana, Sri Suwitri, 2009).

\section{Acknowledgments}

This work is supported by Poltekkes Kemenkes Semarang Director who gave the golden opportunity doing a lot of research. Our 
gratitude goes to the Banyumas District Health Office and the HIV/AIDS Prevention Commission for providing research permits related to patients. especially people living with HIV/AIDS (PLWHA) patients who are willing to become respondents considering the sensitive data taken.

\section{References}

Agustino, L. (2008) Basics of Public Policy Policy Analysis from Formulation to Implementation of State Policy. Bandung: Bumi Aksara.

Commission, A. (2007) Guidelines for the Organization and Working Procedures of the Regional AIDS Commission Secretariat. Jakarta.

Hana, Sri Suwitri, R. S. (2009) ‘Implementation of HIV and AIDS Management Policies in Central Java (Study of Regional Regulation on Central Java Province', 5.

Kemenkes (2017) Guidelines Forhealth Care Facilities Primary. Available at: http://siha.depkes.go.id/portal/files_upl $\mathrm{oad} / 4$

Guidelines_Fasyankes_Primer_ok.pdf.

M. Irfan. (2007) Forms of Social Research., Principles of State Policy Formulation. Jakarta: Rajawali Pers Islamy.

Ministry of Home Affairs. (2004) Law 32 of 2004 concerning Regional Government, Law 32 of 2004 concerning Regional Government. Jakarta, Indonesia.

Moleong, L. J. (2003) Qualitative Research Methodology. Bandung: PT Youth Rosdakarya. Nugroho.

Suharto, E. (2008) Public Policy Formulation, Implementation, and Evaluation. Jakarta: Gramedia.

Thoha, M. (2008) Contemporary Public Administration Science. Jakarta: Kencana Prenada Media Group.

Widodo Joko (2002) 'Public Policy Analysis. Concept and application of the concept of public policy process analysis. First printing', Journal of Public Administration (JAP, 3(Public Policy Analysis. The concept and application of the concept of analysis of public policy processes). 